\title{
Thymoglobulin and Its Use in Renal Transplantation: A Review
}

\author{
Umasankar Mathuram Thiyagarajan ${ }^{a}$ Amirthavarshini Ponnuswamy ${ }^{b}$ \\ Atul Bagulc

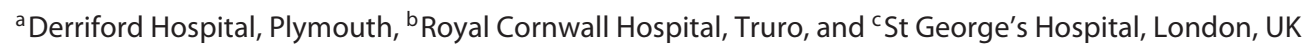

\section{Key Words}

Kidney failure - Transplantation · Rejection .

Immunosuppression

\begin{abstract}
Thymoglobulin (Thymoglobulin ${ }^{\circledR}$; Genzyme, Cambridge, Mass., USA) is a polyclonal antibody which has been used in the field of transplantation over the last four decades. With an initial hesitancy, it is widely used now in the prevention and treatment of rejection following renal transplantation. Thymoglobulin's lack of nephrotoxic properties (unlike calcineurin inhibitors) may potentiate it to be a very useful induction therapy during the early days following transplantation, particularly in a donation after circulatory death programme. More recently its role in conjunction with inhibitors of terminal complement activation has been shown to be beneficial in cross-match-positive transplantation. This review article consolidates up-to-date available evidence to address the therapeutic role of thymoglobulin in immunological tolerance, ischemia perfusion, live donor transplantation, delayed graft function, prevention and treatment of rejection, graft survival and post-transplant lymphoproliferative disorder following renal transplantation.
\end{abstract}

Copyright $\odot 2013$ S. Karger AG, Basel
(C) 2013 S. Karger AG, Basel

0250-8095/13/0376-0586\$38.00/0

\section{Background}

Thymoglobulin (Thymoglobulin ${ }^{\circledR}$; Genzyme, Cambridge, Mass., USA) is a purified polyclonal immunoglobulin used for prevention and treatment of acute rejection (AR) following renal transplantation.

Thymoglobulin is mostly used for treating vascular, steroid-resistant and antibody-mediated rejection. The antirejection efficacy of thymoglobulin was first established in 1999 when compared with equine antithymocyte globulin (eATG) (Pharmacia-Upjohn, Kalamazoo, Mich., USA) [1], and further supported by other studies [2-4]. The history of antilymphoid preparations started in 1899 with Metchnikoff [5]. In 1963, the role of antilymphocyte serum was tested in animals which produced lymphopenia and this led to a new strategy in managing some of the immunological aspects of transplantation [6].

The antilymphocyte serum was first used in human renal transplantation in 1965 [7] and later its use confirmed as an adjuvant immunosuppressant. In 1971, Taylor et al. [8] showed the beneficial use of eATG in a multicentre randomised controlled trial (RCT), but following the discovery of calcineurin inhibitors, a combination of ALG, azathioprine and prednisolone failed to show any advantages over cyclosporine [9]. However, because of

\section{KARGER}

E-Mail karger@karger.com

www.karger.com/ajn
Mr. U. Mathuram Thiyagarajan

Department of General and Transplant Surgery

Derriford Hospital

Plymouth PL6 8DH (UK)

E-Mail umasurgeon@gmail.com 
nephrotoxicity of cyclosporine, some centres used ALG in the early post-operative period and subsequently added cyclosporine A to the immunosuppressant regimen. In 1980, the use of eATG in steroid-resistant allograft rejection was established [10].

Thymoglobulin is prepared by immunizing pathogenfree rabbits with a cell suspension of human thymic tissue (thymocytes). After immunisation, the serum is harvested from rabbits and immunoglobulins against thymocytes are isolated and subjected to a number of purification processes $[3,11,12]$. Samples from more than 26,000 immunised rabbits are pooled to achieve a high level of batch-to-batch consistency $[11,13]$. Since 1984, thymoglobulin has been used effectively in organ transplantation for the prevention and treatment of AR [14].

\section{Mechanism of Action}

The mechanism of polyclonal antilymphocyte preparations on immune responses is still not fully understood. T-cell depletion constitutes the primary mechanism, though other mechanisms, such as modulation of cell surface antigens, emerge as other possible major effectors in the immunological milieu [15].

Thymoglobulin induces lymphocyte depletion in the peripheral blood by complement-dependent cell lysis [16]. Again, this is not the only mechanism as a significant percentage of lymphocyte depletion can be antibody-mediated cytotoxicity and activation-induced cell death [16]. A lower concentration of thymoglobulin in the range of $0.1-1 \mu \mathrm{g} / \mathrm{ml}$ has been shown to induce lysis of preactivated T cells; at a higher concentration (10-100 $\mu \mathrm{g} / \mathrm{ml}$ ) it triggers CD178 (CD95-L) expression by resting T cells and apoptosis of preactivated T cells through pathways mostly involving Fas/Fas-L interactions $[16,17]$.

Lymphocyte depletion occurs rapidly after intravenous administration $[1,3]$ and recovery of peripheral Tcell counts occur gradually after cessation of thymoglobulin treatment. About $40 \%$ patients treated with thymoglobulin (mean of 6 doses at $1.5 \mathrm{mg} / \mathrm{kg} /$ day) recover more than $50 \%$ of initial lymphocyte count at 3 months [1].

In a series of experiments using cynomolgus monkeys, administration of rabbit ATG (rATG) at doses ranging from 1 to $20 \mathrm{mg} / \mathrm{kg}$ was shown to induce transient dosedependent depletion of $\mathrm{CD}^{+}, \mathrm{CD}^{+}, \mathrm{CD}^{+}, \mathrm{CD}^{+}$, $\mathrm{CD} 20^{+}$, and $\mathrm{CD}^{2} 6^{+}$lymphocyte subsets in peripheral blood. It depletes $\mathrm{T}$ cells not only in the periphery but also in secondary lymphoid tissues where the vast majority of $\mathrm{T}$ cells reside and antigen presentation occurs. Notably, no lymphocyte depletion was observed in the thymus at any dosing level [18].

Treatment with rATG down-modulates the expression of several molecules that control T-cell activation, including the T-cell receptor (TCR)/CD3 complex, CD2, CD4, CD5, CD6, and CD8 [18]. Functional antibodies in rATG down-regulate the cell surface expression of a number of integrins and intercellular adhesion molecules (ICAMs) that facilitate leukocyte adhesion to the endothelium [17]. Reperfusion in the presence of rATG thus markedly reduced the rolling of leukocytes and almost completely inhibited the adhesion of leukocytes to the endothelium in a primate model [19].

\section{$B$-Cell Depletion}

rATG has been shown to strongly induce apoptosis in vitro against naive, activated $\mathrm{B}$ cells and bone marrow resident plasma cells at clinically relevant concentrations $(1-100 \mathrm{ng} / \mathrm{ml})$. rATG is thought to bind with numerous $\mathrm{B}$-cell surface proteins and it is this cross-linking of CD30, CD38, CD95, CD80, and HLA-DR that likely accounts for this activity. Fab2 fragments of rATG showed $90 \%$ of the activity of the intact molecule, suggesting participation of the Fc fragment. Inhibition of caspase- and cathepsin-dependent apoptotic pathways partially inhibits rATG-induced B-cell apoptosis [20, 21].

\section{Plasma Cell Depletion}

rATG contains antibodies which can bind syndecan (CD138), a plasma-cell-specific molecule [21], although in vivo ATG treatment is not associated with a reduction in either splenic or bone marrow plasma cells. Clinical studies suggest that rATG may however reduce the risk of AMR in patients with preformed donor-specific antibody [22], presumably by removing $\mathrm{T}$-cell help for alloreactive $B$ cells and via $B$-cell depletion due to antibodies which directly bind B cells [21]. Perry et al. [23] have shown that in vitro rATG failed to inhibit alloantibody production by plasma cells.

Mohty [24] has shown diverse effects of ATG on the immune system; in addition to T-cell depletion, it also induced apoptosis in B-cell lineages, interference with dendritic cell functional properties, and leads to induction of regulatory $\mathrm{T}$ and natural killer $\mathrm{T}$ cells.

Interestingly, Gloor et al. [25] from Mayo Clinic showed that in vivo treated sera from ATG-treated patients produced positive test results for T-cell complement-dependent cytotoxicity and $\mathrm{T}$ - and B-cell flow cytometric (FXM), while the B-cell complement-dependent cytotoxicity cross-match remained negative. Solid-phase 
assays HLA class I and II assays based on antigen-coated microspheres and enzyme-linked immunosorbent assay (ELISA) were minimally affected using in vivo treated sera. After ATG extraction, all tests became negative.

The complex and prolonged immunomodulation induced by ATG contributes to the efficacy of this agent in solid organ transplantation [26]. On assessing leukocyte adhesion by intravital microscope in an ischemia-reperfusion non-human primate model, polyclonal rATGs inhibit early leukocyte interactions with vascular endothelium, almost completely inhibiting the adhesion phenomenon in capillaries which was not seen with the anti-interleukin (IL)-2 receptor monoclonal antibodies [27].

\section{Objectives}

This review is aimed to assess and construct an evidence-based descriptive review document about thymoglobulin use in renal transplantation. It thus aims to address its role in (1) immunological tolerance; (2) ischemia reperfusion injury; (3) delayed graft function; (4) prevention and treatment of acute allograft rejection; (5) live donor transplantation; (6) graft survival and patient surviv$\mathrm{al}$, and (7) post-transplant lymphoproliferative disorder.

\section{Search Strategy}

MEDLINE (PubMed 1966-2012), The Cochrane Central Register of Controlled Trials, EMBASE (1974-2012), the database of Abstracts of Reviews of Effects (DARE), the Health Technology Assessment (HTA) database, and by contacting manufacturers to identify relevant studies, randomised trials, meta-analysis and case series, all related reference articles in English literature were included and reviewed (see PRISMA flow diagram in fig. 1). Studies involving combined renal transplantation were excluded.

\section{Role of Thymoglobulin on Immunological Tolerance}

The regulatory $\mathrm{T}$ cells (Treg), a specialised subset of $\mathrm{T}$ cells shown to play an important role in modulating the immune response to alloantigens and in maintaining selftolerance $[28,29]$, have been identified in patients with stable renal transplant where they may function to maintain the hyporesponsiveness to alloantigen [30]. Thymo- globulin has been shown to cause significant and sustained expansion of Treg in vitro [31]. Lopez et al. [32] demonstrated that thymoglobulin expands the $\mathrm{CD} 4^{+}$, $\mathrm{CD}_{25} 5^{+}$, forkhead box $\mathrm{p} 3\left(\right.$ Foxp $\left.^{+}\right)$Treg population in a dose-dependent manner, primarily by converting $\mathrm{CD} 4^{+}$, $\mathrm{CD} 25^{-}$cells into functionally immunosuppressive $\mathrm{CD} 4^{+}$, $\mathrm{CD} 25^{+}$cells. More importantly, the $\mathrm{CD} 4^{+}, \mathrm{CD} 25^{\text {high }}$ Foxp $3^{+}$Treg cells generated by thymoglobulin were shown to suppress a direct alloimmune response in a mixed lymphocyte reaction, but did not suppress the memory response to recall antigens. LaCorcia et al. [33] showed that clinically relevant doses of thymoglobulin (in vitro) increase functionally immunosuppressive $\mathrm{CD} 4^{+}, \mathrm{CD} 25^{\text {high }}$ Foxp $3^{+}$Treg cells in peripheral blood. Thymoglobulin also effectively inhibits CXCR4-mediated chemotaxis of T cells. All these effects in theory may contribute to durable T-cell anergy and allograft survival.

Recently it has been shown that thymoglobulin can induce B-cell apoptosis on an in vitro model [21]. The recovery of the functional memory of $\mathrm{T}$ cells, considered as a major barrier to the establishment of transplantation tolerance, has been documented after lymphocyte depletion with polyclonal or monoclonal antibody treatment in clinical transplantation $[34,35]$. However, previous in vivo studies have shown that the transplant tolerance can be induced by polyclonal antibody therapy $[36,37]$. rATG in combination with specific donor bone marrow infusion with rapamycin has been shown to be effective in inducing transplant tolerance in major histocompatibility complex mismatched murine skin allograft models $[37,38]$. A recent in vitro study [39] showed that thymoglobulin-pretreated $\mathrm{CD}^{-}$cells demonstrated up-regulation of gene transcripts for CTLA-4, OX40, Foxp3, CD25, interferon- $\gamma$ (IFN- $\gamma$ ), IL-10 and IL-2. Fluorescence-activated cell scanning analysis demonstrated that CD4- cells pretreated with thymoglobulin up-regulated CD25 expression on their surface, and the surface expression of CTLA-4 and OX40 and the expression of intracellular Foxp3 were observed in these CD4-CD25cells. The mixed lymphocyte reaction demonstrated that thymoglobulin-pretreated cells partially inhibited proliferation of untreated autologous $\mathrm{CD} 4^{+}$cells in response to allogenic cells. The lymphocyte proliferation of allogenic mixed lymphocyte reaction was also partially blocked in the presence of supernatants from cultures of thymoglobulin-pretreated $\mathrm{CD}^{+}$cells. This demonstrates that the unique effects of thymoglobulin in modulating $\mathrm{CD}^{+}$cells may be an important mechanism for its action in inducing immunosuppression and transplant tolerance. 
Fig. 1. PRISMA flow diagram.

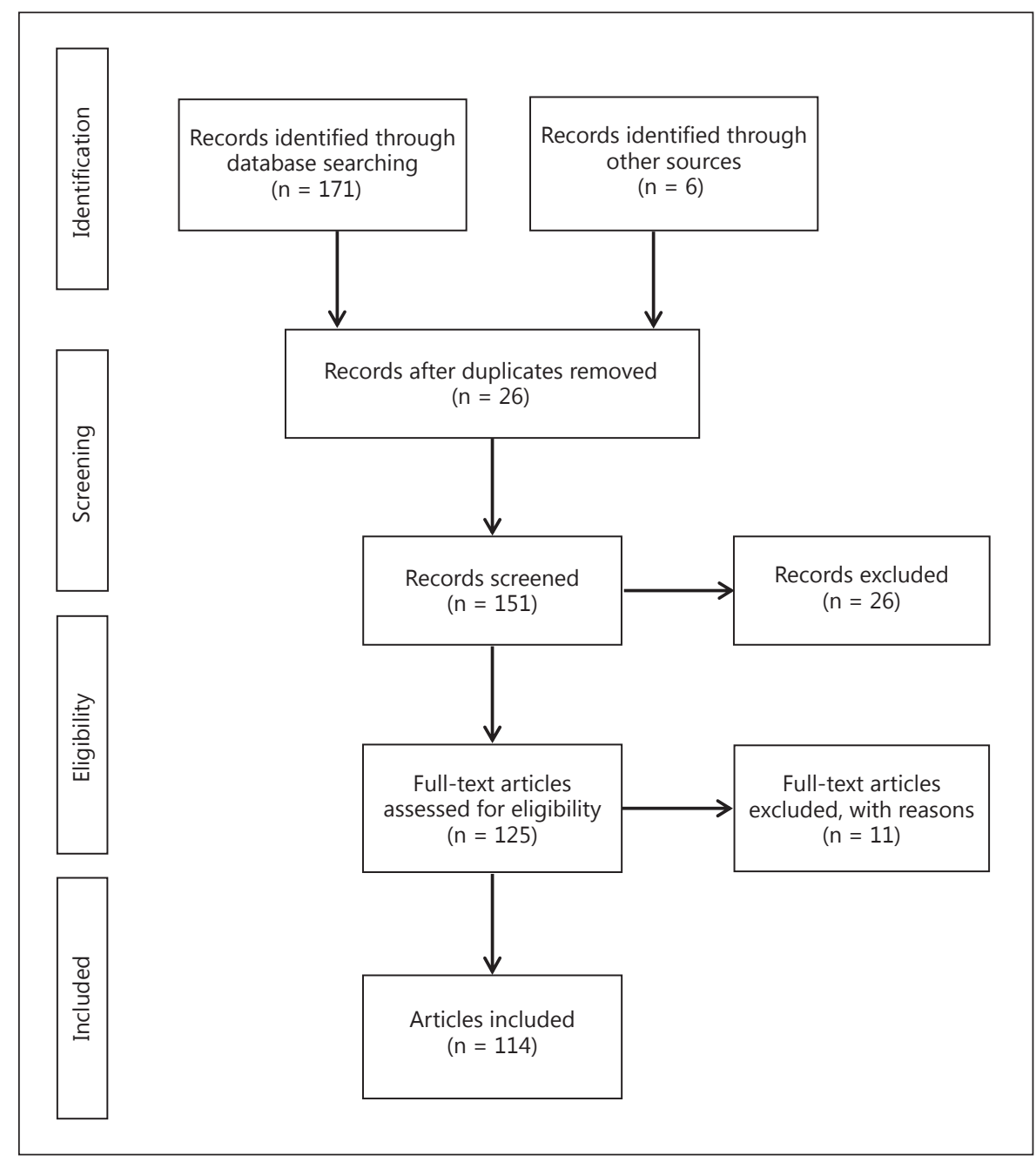

\section{Complication Profile of Thymoglobulin}

Thymoglobulin can cause acute and delayed reactions. Acute reaction will present as cytokine release syndrome which is characterised by anaphylaxis, fever, chills/rigors, dyspnoea, nausea/vomiting, diarrhoea, hypotension or hypertension, malaise, rash, and/or headache which usually can be managed by stopping infusion and epinephrine. Severe reaction includes cardiorespiratory dysfunction including hypotension, pulmonary oedema, myocardial infarction, tachycardia and rarely death [40]. Thymoglobulin is not specific for $\mathrm{T}$ cells but contains antibodies directed against different blood cell types ( $\mathrm{T}$ cells $>\mathrm{B}$ cells; NK cells $>$ monocytes; neutrophils $>$ platelets $>$ erythrocytes) $[18,41]$. Because of the presence of cross-reacting antibodies against non-lymphoid cells, haemolytic anaemia, thrombosis, thrombocytopenia and neutropenia can occur [41].
Delayed reactions usually present as serum sickness and infections. Serum sickness tends to occur 5-15 days after onset of thymoglobulin therapy which presents as fever, rash, arthralgia, and/or myalgia, and are treated with corticosteroids. Despite these adverse effects, thymoglobulin has been shown to be safe in renal transplant recipients when administered in a planned and monitored setting.

\section{Thymoglobulin and Infectious Complications}

Infectious complications include cytomegalovirus (CMV) infection (13.4\%), sepsis (12.2\%), candidiasis (3.7\%), herpes simplex (4.9\%) and urinary infections (18.3\%). These infectious episodes were present when the total dose of thymoglobulin was $>7 \mathrm{mg} / \mathrm{kg}$ [42]. 
Although most studies have shown a tendency to lower the incidence of CMV infections with basiliximab (Simulect ${ }^{\circledR}$; Novartis Pharmaceuticals, Surrey, UK) compared to thymoglobulin [43, 44], Brennan et al. [45] in a cohort of 277 patients documented an incidence of CMV at $13.2 \%$ in the basiliximab group compared $7.1 \%$ in the ATG group. Similarly, a RCT reported a higher incidence of CMV infection in the daclizumab group compared to the thymoglobulin group (18/25 vs. $6 / 25 ; \mathrm{p}=0.03)$ [46].

A multicentre, randomised trial using daclizumab (humanised IgG1 monoclonal antibody) versus thymoglobulin showed that the incidence of CMV infection/ syndrome/disease was 39 versus $51 \%$ in thymoglobulin group ( $\mathrm{p}=\mathrm{NS}$ ). Patients and graft survivals and the incidence of biopsy-proven acute rejection (BPAR) were also identical [47].

A prospective, randomised, multicentre study on live donor recipients showed that the overall incidence of infections was comparable between the thymoglobulin group (39.8\%) and in no antibody at induction (45.8\%, $\mathrm{p}=\mathrm{NS}$ ) [48]. There was no difference in the immunosuppressive regimen between the groups.

\section{Role of Thymoglobulin in Ischemia-Reperfusion Injury}

Ischemia-reperfusion injury (IRI) is an acute inflammatory process by which transplanted cells and organs are damaged first by ischemia and later by reperfusion, which leads to cell dysfunction and cell death [49]. The pathogenesis of renal IRI is multifactorial and initially relates to the hypoxic and anoxic cell injuries during the ischemic phase, followed by inflammatory responses during the reperfusion phase. The $\mathrm{T}$ cells have been attributed to play a significant role in the pathogenesis of renal IRI [50-52]. Studies have shown both direct and indirect blockade of $\mathrm{T}$ cells reduced renal functional and structural injury in murine renal IRI models [51-53]. In athy$\mathrm{mic}$ nu/nu mice (T-cell knockout mouse strain) subjected to IRI, not only protection from initial renal injury but also an adoptive T-cell transfer into these mice restored the renal injury [54]. Inactivation of these cells is a prerequisite to achieve some protection against IRI [54].

IRI is associated with an increased rate of $A R$, primary non-function, delayed graft function (DGF) and also late graft failure leading to graft loss $[41,55]$. Beiras-Fernandez et al. [56] performed a study in cynomolgus monkeys to evaluate the effect of ATG following IRI. This study demonstrated that the expression of all adhesion mole- cules (ICAM-1, VCAM, PECAM, CD11b, and CD62e) were significantly lower when compared to the control group. The expression of IL-1, IL- 6 and TNF- $\alpha$ were also reduced in ATG group.

Jang et al. [57] investigated the effect of mouse ATG (mATG) in a mouse renal IRI model to assess the effect of mATG following warm renal IRI. Though the mATG effectively depleted the circulating $\mathrm{T}$ cells, it seemed to have less effect on kidney-infiltrating T cells. Similarly, there was no difference in serum creatinine, tubular damage and tubular regeneration. $\mathrm{mATG}$ did not alter the expression of cytokines (IFN- $\gamma$, IL-10). Larger amounts of mATG were needed to achieve a similar degree of T-cell depletion effect as seen in patients treated with smaller doses of ATG, hence limiting a direct implication of these results to a clinical setting.

\section{Role of Thymoglobulin in Prevention of Delayed Graft Function (table 1)}

DGF is defined as a need of dialysis in the first week following transplantation. The incidence of DGF depends on multiple factors including obesity, high donor creatinine, panel-reactive antibody (PRA), race, old donor or recipient age, and long cold ischemia time. A randomised, double-blinded study [1] showed that a 7-day induction course with polyclonal rATG resulted in a less frequent and less severe rejection, better event-free survival, and fewer serious adverse events compared with induction with polyclonal eATG (Atgam). In this study, the authors suggested that the intraoperative administration of rATG may have helped to decrease DGF and possibly by blocking the adhesion molecules that play a role in IRI.

However, in another prospective, randomised, international study on high-risk recipients of deceased donors, similar findings could not be replicated [45]. Here patients were randomly assigned to receive either rATG $(1.5 \mathrm{mg} / \mathrm{kg}$ b.w. daily, 141 patients) during transplantation (day 0 ) and on days 1 through 4 or basiliximab (20 $\mathrm{mg}, 137$ patients) on days 0 and 4 . Although thymoglobulin reduced the incidence and severity of $A R$, it did not show any effect on the incidence of DGF.

Goggins et al. [58] conducted a randomised, clinical trial of intraoperative versus post-operative thymoglobulin in adult deceased donor renal transplant recipients. This study showed that intraoperative administration before allograft reperfusion is associated with a significant decrease in DGF, a better early allograft function in the first month post-transplant, and a decrease in post-trans- 
Table 1. Role of Thymo in DGF

\begin{tabular}{|c|c|c|c|c|c|c|}
\hline $\begin{array}{l}\text { Study (country) } \\
\text { period }\end{array}$ & $\begin{array}{l}\text { Time of usage and } \\
\text { numbers }\end{array}$ & DGF & BPAR & $\begin{array}{l}\text { Graft } \\
\text { survival } \\
1 \text { year }\end{array}$ & $\begin{array}{l}\text { Patient } \\
\text { survival } \\
1 \text { year }\end{array}$ & Comments \\
\hline $\begin{array}{l}\text { Brennan et al. [1] } \\
\text { (USA), 1996-1997 }\end{array}$ & $\begin{array}{l}\text { At induction and } 7 \text { days } \\
\text { following transplantation } \\
\text { Thymo }=48 \\
\text { Atgam }=24\end{array}$ & $\begin{array}{l}1 \% \text { incidence } \\
\text { of DGF in total }\end{array}$ & $\begin{array}{l}\text { Thymo }=4 \% \\
\text { Atgam }=25 \% \\
(\mathrm{p}=0.014) \\
\text { BPAR }=\text { Thymo }<\text { Atgam } \\
(\mathrm{RR}=0.09 ; \mathrm{p}=0.009)\end{array}$ & $\begin{array}{l}98 \% \\
83 \%\end{array}$ & $\begin{array}{l}98 \pm 2 \% \\
96 \pm 4 \%\end{array}$ & $\begin{array}{l}\text { Double-blind randomised study: } \\
\text { high-risk }(\mathrm{DD}+\mathrm{LD}) \text { recipients } \\
\text { Rejection was less severe in Thymo than } \\
\text { Atgam }(\mathrm{p}=0.014)\end{array}$ \\
\hline $\begin{array}{l}\text { Goggins et al. [58] } \\
\text { (USA), 2001-2002 }\end{array}$ & $\begin{array}{l}\text { Intra- vs. post-operative } \\
\text { Thymo }\end{array}$ & $\begin{array}{l}14.5 \% \\
35.5 \% \\
(p=0.05)\end{array}$ & $\begin{array}{l}3.6 \% \\
16 \% \\
(\mathrm{p}=0.11)\end{array}$ & N/A & N/A & $\begin{array}{l}\text { DD recipients } \\
\text { Prospective randomised study } \\
3-6 \text { doses Thymo was during the 1st week }\end{array}$ \\
\hline $\begin{array}{l}\text { Patel et al. [59] } \\
\text { (USA), 2004-2005 }\end{array}$ & $\begin{array}{l}\text { Intra- and post- } \\
\text { operative administration } \\
\text { with total of } 3-7 \text { doses }\end{array}$ & N/A & N/A & N/A & $\begin{array}{l}97 \% \\
98 \%\end{array}$ & $\begin{array}{l}\text { Retrospective study: DD recipients } \\
\text { BPAR at } 36 \text { months was } 11 \% \text { non-DGF } \\
\text { group and } 22.4 \% \text { in DGF group }(\mathrm{p}=0.025)\end{array}$ \\
\hline $\begin{array}{l}\text { Noël et al. [60] } \\
\text { (France and Belgium), } \\
2001-2005\end{array}$ & $\begin{array}{l}\text { Pre- and post-operative } \\
\text { therapy } \\
\text { Thymo }=114 \\
\text { Dac }=119\end{array}$ & $\begin{array}{l}31.5 \% \\
44.6 \% \\
(\mathrm{p}=0.04)\end{array}$ & $\begin{array}{l}15 \% \\
27.2 \% \\
(p=0.01)\end{array}$ & $\begin{array}{l}17.7 \% \\
14 \%\end{array}$ & $\begin{array}{l}\text { No } \\
\text { difference }\end{array}$ & $\begin{array}{l}\text { Prospective multicentred trial: } \\
\text { high immunological DD recipients } \\
\text { Tacrolimus, MMF and steroids } \\
\text { immunosuppression }\end{array}$ \\
\hline $\begin{array}{l}\text { Lebranchu et al. [43] } \\
\text { (France), 1998-2000 }\end{array}$ & $\begin{array}{l}\text { Pre- and post-operative } \\
\text { therapy } \\
\text { Thymo }=50 \\
\text { Bas }=50\end{array}$ & $\begin{array}{l}6 \% \\
14 \% \\
(p=N S)\end{array}$ & $\begin{array}{l}8 \% \\
8 \%\end{array}$ & $94 \%$ & $98 \%$ & $\begin{array}{l}\text { Open, randomized, multicentre study: } \\
\text { DD recipients } \\
\text { Delayed introduction of CsA, MMF and } \\
\text { steroids in the Thymo group }\end{array}$ \\
\hline $\begin{array}{l}\text { Abou-Ayache } \\
\text { et al. [47] } \\
\text { (France), } 2008\end{array}$ & $\begin{array}{l}\text { Pre- and post-operative } \\
\text { therapy } \\
\text { Thymo }=55 \\
\text { Dac }=54\end{array}$ & $\begin{array}{l}36 \% \\
32 \%\end{array}$ & $\begin{array}{l}14.5 \% \\
16.7 \%\end{array}$ & $\begin{array}{l}98 \% \\
94 \%\end{array}$ & $\begin{array}{l}98 \% \\
95 \%\end{array}$ & $\begin{array}{l}\text { Prospective, randomized, multicentre trial } \\
\text { Delayed introduction of CsA, MMF and } \\
\text { steroids in the Thymo group }\end{array}$ \\
\hline
\end{tabular}

Thymo = Thymoglobulin; Dac = Daclizumab; Bas = Basiliximab; DGF = delayed graft function; BPAR = biopsy-proven acute rejection; CsA = cyclosporine; $\mathrm{DD}=$ deceased donors; $\mathrm{LD}=$ live donors.

plant hospital length of stay. The dose-dependent depletion of T cells achieved by rATG [42] may also play a role in the attenuation of graft IRI.

Patel et al. [59] demonstrated that a high BMI (>30), sirolimus-based regimen, female to male donation and donor creatinine $>1.5 \mathrm{mg} / \mathrm{dl}$ are independent risk factors for DGF. The patients with DGF had a worse survival compared to non-DGF group at 1 year. Patients with moderate PRA (10-50\%) to a high ( $>50 \%)$ level of sensitisation who received ATG had fewer incidences of DGF and BPAR, indicating an impact for induction therapy.

A multicentre trial on high-risk deceased donor kidney recipients showed that the incidence of DGF was low in patients who received thymoglobulin compared with daclizumab [60]. The incidence of DGF was 31.5 and $44.6 \%$ in the thymoglobulin and daclizumab groups, respectively. More significantly, the incidence of rejection is also low in patients receiving thymoglobulin (15 vs. $27.2 \%$; $\mathrm{p}=0.01$ ).

Thymoglobulin in Renal Transplantation
Another randomised study investigated the role of thymoglobulin versus basiliximab on deceased donor renal transplant recipients; here the thymoglobulin group had delayed introduction of cyclosporine [43]. The incidence of DGF and BPAR was similar in both groups. Similar findings were reported in another multicentre prospective study by Abou-Ayache et al. [47].

\section{Role of Thymoglobulin on Biopsy-Proven Acute Rejection (table 2)}

Two events occurring early in the post-transplantation period, AR and DGF, negatively affect graft survival $[61,62]$. Patients with DGF have an increased risk of AR, and graft survival is superior in patients who have neither DGF nor AR $[63,64]$.

Brennan et al. [45] conducted a prospective, randomised, international, multicentre study to compare short courses of thymoglobulin and basiliximab in high- 
Table 2. Role of Thymo in BPAR

\begin{tabular}{|c|c|c|c|c|c|c|}
\hline $\begin{array}{l}\text { Study (country) } \\
\text { period }\end{array}$ & $\begin{array}{l}\text { Time of usage } \\
\text { and numbers }\end{array}$ & DGF & BPAR & $\begin{array}{l}\text { Graft } \\
\text { survival } \\
1 \text { year }\end{array}$ & $\begin{array}{l}\text { Patient } \\
\text { survival } \\
1 \text { year }\end{array}$ & Comments \\
\hline $\begin{array}{l}\text { Brennan DC } \\
\text { et al. [45] } \\
\text { (USA), 2006 }\end{array}$ & $\begin{array}{l}\text { Bas (days } 0 \text { \& } 4 \text { ) } \\
\text { Thymo (days } 1 \& 4 \text { ) } \\
\text { Thymo }=141 \\
\text { Bas }=137\end{array}$ & $\begin{array}{l}\text { Thymo }=40.4 \% \\
\text { Bas }=44.5 \% \\
(p=N S)\end{array}$ & $\begin{array}{l}\text { Thymo }=15.6 \% \\
\text { Bas }=25.5 \% \\
(p=0.02)\end{array}$ & $\begin{array}{l}9.2 \% \\
10.2 \%\end{array}$ & $\begin{array}{l}95.7 \% \\
95.6 \%\end{array}$ & $\begin{array}{l}\text { Prospective randomised trial: } \\
\text { DD recipients } \\
\text { BPAR was less severe in Thymo } \\
\text { than Bas }(\mathrm{p}=0.02)\end{array}$ \\
\hline $\begin{array}{l}\text { Martin } \\
\text { et al. [65] (USA), } \\
\text { 2004-2007 }\end{array}$ & $\begin{array}{l}\text { At induction } \\
\text { Thymo }=68 \\
\text { Bas }=31\end{array}$ & N/A & $\begin{array}{l}\text { Thymo }=7 \% \\
\text { Bas }=26 \% \\
(p=0.02)\end{array}$ & $\begin{array}{l}0 \% \\
3 \% \\
(p=0.31)\end{array}$ & $\begin{array}{l}2 \% \\
0 \%\end{array}$ & $\begin{array}{l}\text { Single-centre, retrospective study: } \\
\text { DD or LD recipients } \\
\text { Thymo }=\downarrow \text { frequency and delayed } \\
\text { onset of BPAR }\end{array}$ \\
\hline $\begin{array}{l}\text { Kamel et al. [66] } \\
\text { (Ireland), } \\
\text { 1986-1998 }\end{array}$ & $\begin{array}{l}63 \text { patients received none } \\
\text { Thymo }=59 \text { on } 6-10 \text { days }\end{array}$ & N/A & $\begin{array}{l}19.7 \% \\
3.3 \% \\
(p=0.008)\end{array}$ & N/A & $\begin{array}{l}62 \% \\
90 \% \\
(p=0.001)\end{array}$ & $\begin{array}{l}\text { Retrospective study: DD recipients } \\
\text { Thymo } \uparrow \text { graft survival }\end{array}$ \\
\hline $\begin{array}{l}\text { Tian et al. [68] } \\
\text { (China), 2009 }\end{array}$ & $\begin{array}{l}\text { Induction with Thymo } \\
\text { versus no inducing agents }\end{array}$ & $\mathrm{N} / \mathrm{A}$ & $\begin{array}{l}\text { BPAR at } 6 \text { months } \\
\text { (RR 0.68; 95\% CI 0.49-0.96) } \\
\text { at } 1 \text { year } \\
\text { RR } 0.70 ; 95 \% \text { CI } 0.57-0.84 \text { ) }\end{array}$ & $\mathrm{N} / \mathrm{A}$ & $\mathrm{N} / \mathrm{A}$ & $\begin{array}{l}\text { Meta-analysis of randomised } \\
\text { controlled trials } \\
\text { There was no statistical difference } \\
\text { in PS or GS rates at } 6 \text { and } 12 \\
\text { months }\end{array}$ \\
\hline $\begin{array}{l}\text { Brennan DC } \\
\text { et al. [1] (USA), } \\
1996-1997\end{array}$ & $\begin{array}{l}\text { At induction and } \\
7 \text { days following } \mathrm{Tx} \\
\text { Thymo }=48 \\
\text { Atgam }=24\end{array}$ & $\begin{array}{l}1 \% \text { incidence of } \\
\text { DGF in total }\end{array}$ & $\begin{array}{l}\text { Thymo }=4 \% \\
\text { Atgam }=25 \%(\mathrm{p}=0.014) \\
\text { BPAR in Thymo }<\text { Atgam } \\
(\mathrm{RR}=0.09 ; \mathrm{p}=0.009)\end{array}$ & $\begin{array}{l}98 \% \\
83 \%\end{array}$ & $\begin{array}{l}98 \pm 2 \% \\
96 \pm 4 \%\end{array}$ & $\begin{array}{l}\text { Double-blind randomised study: } \\
\text { high-risk }(\mathrm{DD}+\mathrm{LD}) \text { recipients. } \\
\text { BPAR was less severe in Thymo } \\
\text { than Atgam }(\mathrm{p}=0.014)\end{array}$ \\
\hline $\begin{array}{l}\text { Knight et al. [70] } \\
\text { (USA), } \\
1998-2002\end{array}$ & $\begin{array}{l}\text { Pre- and post-operative } \\
\text { therapy } \\
\text { Thymo }=30 \\
\text { Bas }=115\end{array}$ & $14 \%$ had DGF & $\begin{array}{l}\text { Thymo }=3 \% \\
\text { Bas }=26 \% \\
(p=0.01)\end{array}$ & $88 \%$ & $94 \%$ & $\begin{array}{l}\text { Retrospective study: high-risk DD } \\
\text { recipients }\end{array}$ \\
\hline $\begin{array}{l}\text { Libório et al. [71] } \\
\text { (Brazil), } \\
2002-2009\end{array}$ & $\begin{array}{l}\text { Pre- and post-operative } \\
\text { therapy } \\
\text { Thymo }=88 \\
\text { Dac/Bas }=79\end{array}$ & $\begin{array}{l}35.2 \% \\
32.9 \%\end{array}$ & $\begin{array}{l}11.4 \% \\
25.6 \% \\
(p=N S)\end{array}$ & $\begin{array}{l}95.5 \% \\
83.5 \% \\
\text { at } 5 \text { years }\end{array}$ & $\begin{array}{l}99 \% \\
97.2 \% \\
\text { at } 3 \text { years }\end{array}$ & $\begin{array}{l}\text { Retrospective study: DD recipients } \\
\text { with an aim to early steroid } \\
\text { withdrawal }\end{array}$ \\
\hline $\begin{array}{l}\text { Cianco et al. [72] } \\
\text { (USA), 2002-2004 }\end{array}$ & $\begin{array}{l}\text { Pre- and post-operative } \\
\text { therapy } \\
\text { Thymo }=30 \\
\text { Cam }=30 \\
\text { Dac }=30\end{array}$ & $\begin{array}{l}13.3 \% \\
6.7 \% \\
6.7 \%\end{array}$ & $\begin{array}{l}16.6 \% \\
16.6 \% \\
16.6 \%\end{array}$ & $\begin{array}{l}92 \% \\
100 \% \\
88 \% \\
(p=N S)\end{array}$ & $\begin{array}{l}88 \% \\
100 \% \\
88 \% \\
(p=N S)\end{array}$ & $\begin{array}{l}\text { Randomised study: DD recipients. } \\
\text { Campath arm: } 80 \% \text { steroid-free at } \\
1 \text { year } \\
\text { No difference in PS or GS rates at } \\
6 \text { and } 12 \text { months }\end{array}$ \\
\hline
\end{tabular}

See table 1 for abbreviations.

risk recipients for AR or DGF. The incidence and severity of AR was lower in the thymoglobulin group than in the basiliximab group. The study also showed the incidence of BPAR among patients who received basiliximab was more than 1.5 times than among those who received thymoglobulin. The incidence of CMV disease was lower in the ATG group than in the basiliximab group with appropriate prophylaxis in high-risk patients. Similarly, Martin et al. [65] showed that induction with rATG was associated with a lower frequency and delayed onset of BPAR when compared to a similar cohort of patients receiving.
Kamel et al. [66] reported that ATG increases the transplantation cost initially, but it is eventually offset by a decrease in overall immunosuppressive and rehospitalisation costs. Shenoy et al. [67] have recently published that ATG therapy in corticosteroid-resistant acute allograft rejection is associated with reversal of rejection and excellent graft outcome in paediatric transplants.

A recent meta-analysis of randomised trials has confirmed the role of ATG in prevention of AR episodes and chronic rejection responses after renal transplantation [68]. In addition, a multivariate analysis on antibody induction also confirmed reduction in BPAR [69]. A dou- 
Table 3. Role of thymoglobulin in live donor transplantation

\begin{tabular}{|c|c|c|c|c|c|c|}
\hline $\begin{array}{l}\text { Study (country) } \\
\text { period }\end{array}$ & $\begin{array}{l}\text { Time of usage } \\
\text { and numbers }\end{array}$ & DGF & BPAR & $\begin{array}{l}\text { Graft survival } \\
1 \text { year }\end{array}$ & $\begin{array}{l}\text { Patient survival } \\
1 \text { year }\end{array}$ & Comments \\
\hline $\begin{array}{l}\text { Hardinger et al. } \\
\text { [75] (USA), } \\
1996-2003\end{array}$ & Thymo $=214$ & $0 \%$ & $\begin{array}{l}2 \% \text { rejection at } \\
1 \text { year }\end{array}$ & $8 \%$ & $92 \%$ & $\begin{array}{l}\text { Retrospective study } \\
\text { Better outcomes compared with the } \\
\text { national statistics }\end{array}$ \\
\hline $\begin{array}{l}\text { Woodle et al. } \\
\text { [48] (USA), } 2010\end{array}$ & $\begin{array}{l}\text { Thymo }=103 \\
\text { No Thymo }=48\end{array}$ & $\begin{array}{l}1.9 \% \\
2.1 \%\end{array}$ & $\begin{array}{l}\text { Thymo }=13.9 \% \\
\text { No Thymo }=19.4 \% \\
(p=N S)\end{array}$ & No difference & $\begin{array}{l}\text { No } \\
\text { difference }\end{array}$ & $\begin{array}{l}\text { Multicentre, prospective } \\
\text { randomised study }\end{array}$ \\
\hline $\begin{array}{l}\text { Gaber et al. [76] } \\
\text { (USA), 2003-2008 }\end{array}$ & Thymo $=2,322$ & $\mathrm{~N} / \mathrm{A}$ & $8.3 \%$ & $98.2 \%$ & $98.4 \%$ & $\begin{array}{l}\text { Multicentre, prospective study on in } \\
\text { LD transplantation (Tailor Registry) }\end{array}$ \\
\hline $\begin{array}{l}\text { Schenker et al. [77] } \\
\text { (Germany), } \\
2002-2010\end{array}$ & $\begin{array}{l}\text { Single-dose Thymo } \\
\text { at induction } \\
\text { Living related }=60 \\
\text { Living unrelated }=40\end{array}$ & N/A & $\begin{array}{l}17 \% \\
35 \% \\
(p=0.035)\end{array}$ & $\begin{array}{l}93 \% \\
95 \%\end{array}$ & $\begin{array}{l}97.4 \% \\
98.3 \%\end{array}$ & $\begin{array}{l}\text { Retrospective case series } \\
\text { Incidence of CMV infection (10\%), } \\
\text { polyomavirus infection (5\%), } \\
\text { malignancy }(4 \%) \text {, and PTLD (0\%) }\end{array}$ \\
\hline
\end{tabular}

Cam = Campath $(1 \mathrm{H}) ; \mathrm{LD}=$ live donors; CMV = cytomegalovirus; PTLD = post-transplant lymphoproliferative disorder. See table 1 for further abbreviations.

ble-blinded randomised study on high-risk recipients demonstrated that thymoglobulin was superior in preventing BPAR compared with Atgam (4 vs. $25 \%$; $\mathrm{p}=$ $0.009)$ [1]. This finding was also supported by a retrospective study where thymoglobulin versus basiliximab was investigated in high-risk deceased donor recipients [70].

An interesting study investigated the use of thymoglobulin versus daclizumab/basiliximab in a deceased donor kidney recipient where the aim of early withdrawal failed to show any difference in the incidence of BPAR (11.4 vs. $25.6 \% ; \mathrm{p}=\mathrm{NS}$ ) [71]. A similar finding was reported in another randomised study [72]. These studies have demonstrated the feasibility of these agents in an early steroid withdrawal without increasing the risk of rejection.

Thus, most studies have shown thymoglobulin usage to be superior in preventing BPAR when compared with other agents in high-risk patients, without increasing the risk of opportunistic infections and post-transplantation lymphoproliferative disease [45].

\section{Role of rATG in Live Donor Transplantation (table 3)}

Live donor renal transplantation was believed to be associated with a lower incidence of BPAR, which is not the case. In 2003, a retrospective Australian study [73] of
498 kidney transplant recipients showed a higher incidence of AR in live donor recipients than in deceased donor renal transplant recipients ( 44 vs. $28 \%$, respectively, $\mathrm{p}=0.001$ ). In this study, induction therapy was given only to recipients considered at high risk for rejection (8 vs. $20 \%$ ). Similar observations were also noted in another study [74].

A retrospective analysis of 214 patients induced with rATG [75] showed that DGF was statistically lower ( $0 \%$ centre cohort vs. $5 \%$ national data, $\mathrm{p}=0.001)$. The 1 -year AR rate was $2 \%$ in the centre cohort versus $21 \%$ in national data $(\mathrm{p}<0.001)$. A recent study conducted using thymoglobulin versus basiliximab monoclonal antibody in live donor renal transplantation has shown that thymoglobulin was associated with a decreased risk of BPAR with no difference on graft survival at 5 years [69].

A prospective, randomised, multicentre study evaluated the early corticosteroid withdrawal (ECSWD) with thymoglobulin in living donor kidney transplantation [48]. In this study the authors reported ECSWD with thymoglobulin induction to chronic corticosteroid therapy (CCST) without antibody induction in primary, living donor renal transplant recipients. Among 151 recipients, 103 received thymoglobulin (ECSWD group) and 48 received no antibody therapy at induction (CCST). There 
were no significant differences in BPAR, graft loss, and death at 6 months ( 85.4 vs. $85.4 \%$ ) or 12 months (84.4 vs. $74.4 \%$ ) in the ECSWD group versus the CCST group. No differences were observed in serious adverse events or infectious complications, with the exception of a higher incidence of leukopenia with ECSWD.

A recent prospective, multicentre study that assessed the efficacy of thymoglobulin in live donor transplants reported a low incidence of BPAR (Tailor Registry) [76]. Schenker et al. [77] performed a retrospective study on live donor recipients who had received a single dose of thymoglobulin before transplantation, and demonstrated the beneficial effect thymoglobulin on reducing the BPAR without increasing the incidence of CMV infection. Another comparative study investigated thymoglobulin versus alemtuzumab (Campath-1H) in living donor recipients who showed no difference in the incidence of BPAR, graft survival and patient survival [78].

DGF following live donor renal transplantation is not uncommon and this can be reduced significantly by using thymoglobulin [75]. Usage of thymoglobulin in live donor recipients is not only safe, but it is well established for reducing BPAR.

\section{Role of Thymoglobulin on Graft Survival and Patient Survival Rate}

Both DGF and AR in the first year are independent risk factors for graft survival. A retrospective study showed an increased long-term graft survival in patients treated with ATG [79]. In this study the ATG group consisted of high-risk recipients including more hypersensitised, younger patients, second transplant, and cadaveric donors. The final endpoint, a better long-term graft survival was observed $(p=0.003)$. This benefit was independent of recipient age, race and gender, primary cause of renal failure, pretransplant dialysis time, immunological risk, HLA mismatch, donor age, gender and occurrence of DGF. A similar finding has been reported in another study [80]. Shenoy et al. [67] showed that ATG therapy in early-onset corticosteroid-resistant AR is associated with an excellent graft outcome in children. Thus it appears that rATG increases graft survival even in high-risk patients and this result is independent of other risk factors. Hardinger et al. [75] showed that the patient survival rate (live donor transplants) was improved with thymoglobulin ( $96 \%$ centre cohort vs. $90 \%$ national data; $\mathrm{p}=0.03)$.

\section{Interleukin-2 Receptor Antibody versus} Thymoglobulin in Renal Transplantation

Basiliximab is a chimeric monoclonal antibody (murine/human) with human IgG1 constant heavy chain regions and $\kappa$ light chain. It specifically binds and blocks CD25 antigen, IL-2r $\alpha$-chain, at the surface of activated T lymphocytes.

A well-structured, prospective, randomised, international study compared a short course of thymoglobulin and basiliximab in patients at high risk of AR or DGF who received a kidney from deceased donors [45]. All patients received cyclosporine, mycophenolate mofetil and prednisolone as maintenance immunosuppression. Thymoglobulin was given $1.5 \mathrm{mg} / \mathrm{kg}$ on day 0 and days 1 through 4 , and basiliximab $20 \mathrm{mg}$ intravenously on days 1 and 4 . The thymoglobulin group had a lower incidence of BPAR ( 15.6 vs. $25.5 \%$; $p=0.02$ ) when compared with the basiliximab group. The severity of the AR was lower in the thymoglobulin group than the basiliximab group. Other than this, graft loss, DGF, CMV disease and death were similar in both groups.

However, since this study was published, tacrolimus has been widely used and has replaced cyclosporine. Willoughby et al. [81] performed a retrospective analysis on 19,137 patients to compare the graft outcomes according to antibody induction regimens within registrar data of the Organ Procurement and Transplantation Network (OPTN). The primary outcome was the 6-month composite endpoint of rejection, graft failure, or death. Thymoglobulin was shown to be associated with a superior outcome compared to basiliximab, but there is to date no RCT available to weigh thymoglobulin versus basiliximab in tacrolimus-based immunosuppression.

A multicentre, randomised study [82] specifically addressed the use of an anti-CD25 monoclonal antibody daclizumab (Zenapax ${ }^{\circledR}$; Hoffmann-La Roche, Basel, Switzerland) versus thymoglobulin in high-risk renal transplant recipients (TAXI Study). High-risk recipients were defined as PRA $>30 \%$, peak PRA $>50 \%$, loss of kidney from rejection within last 2 years of transplantation, or two or three previous grafts. Thymoglobulin was administered daily between day 0 and day 7 at a dose of $1.25 \mathrm{mg} /$ $\mathrm{kg} /$ day and five injections of daclizumab were administered at a dose of $1 \mathrm{mg} / \mathrm{kg}$ on days $0,14,28,42$ and 56 . The maintenance immunosuppression was tacrolimus, mycophenolate mofetil and steroids and the primary endpoint was BPAR. The thymoglobulin group had a lower incidence of both BPAR (15.0 vs. $27.2 \%$; $\mathrm{p}=0.016)$ and steroid-resistant rejection ( 2.7 vs. $14.9 \% ; \mathrm{p}=0.002)$ at 1 year. 
One-year graft and patient survival rates were similar in the two groups. A comparison of rejecters and non-rejecters showed that overall graft survival was significantly higher in the rejection-free group $(87.2$ vs. $75.0 \%$; $\mathrm{p}=$ 0.037 ). The DGF occurred in $31.5 \%$ of thymoglobulin group and $44.6 \%$ in the daclizumab group $(\mathrm{p}=0.04)$. The study concluded that thymoglobulin is superior to daclizumab for the prevention of BPAR among high-immunological-risk renal transplant recipients. No difference in the incidence of CMV infection was seen between these groups. This result was supported by another multicentred RCT which showed no difference in the incidence of $\mathrm{CMV}$ infection/syndrome/disease at 1 year, although the mean number of pp65-positive cells was lower in the daclizumab group [47]. However, this trial used a cyclosporine-based maintenance immunosuppression regimen.

\section{Alemtuzumab versus Thymoglobulin in Renal Transplantation}

Alemtuzumab (MabCampath or Campath; Genzyme) is humanised rat monoclonal CD52 antibody that causes prolonged and sustained lymphopenia [83]. It specifically acts on mononuclear cells [84] and has been used as a therapeutic agent in solid organ transplantation but is limited to B-cell chronic lymphocytic leukaemia $[85,86]$. Thomas et al. [87] addressed its use in a prospective RCT on recipients with high immunological risks. Recipients received either a single dose of alemtuzumab before the graft perfusion with tacrolimus monotherapy or four doses of thymoglobulin. One-year cumulative graft survival was $85.7 \%$ for the alemtuzumab group and $87.5 \%$ for the thymoglobulin group. The infection and rejection rates were not different between these groups.

Another interesting randomised trial [72] was done using three different antibodies at induction and primarily to assess the safety of alemtuzumab with a lower dose of tacrolimus, mycophenolate mofetil and steroid avoidance. Groups A, B and C received thymoglobulin, alemtuzumab and daclizumab, respectively. Maintenance immunosuppression included tacrolimus and mycophenolate in all three arms and steroids in groups $\mathrm{A}$ and $\mathrm{C}$ only. There was no difference in BPAR, CMV infection rate, patient and graft survival.

A recent prospective study evaluated the efficacy of alemtuzumab in high- and low-risk patients compared to basiliximab and thymoglobulin [88]. Among 139 highrisk patients, 70 received alemtuzumab (one dose of 30 $\mathrm{mg}$ ) and 69 had thymoglobulin (a total of $6 \mathrm{mg} / \mathrm{kg}$ b.w.

Thymoglobulin in Renal Transplantation given over 4 days). The 335 low-risk patients received alemtuzumab (one dose of $30 \mathrm{mg}$ in 164 patients) or basiliximab (a total of $40 \mathrm{mg}$ over 4 days in 171 patients). All patients received tacrolimus and mycophenolate mofetil and underwent a 5-day steroid taper in a regimen of early steroid withdrawal. The rate of BPAR was significantly lower in the alemtuzumab group than in the conventional therapy group at both 6 months ( 3 vs. $15 \%, \mathrm{p}<0.001$ ) and 12 months ( 5 vs. $17 \%, \mathrm{p}<0.001$ ). At 3 years, the rate of biopsy-confirmed AR in low-risk patients was lower with alemtuzumab than with basiliximab ( $10 \mathrm{vs.} 22 \%, \mathrm{p}=$ 0.003 ), but among high-risk patients, no significant difference was seen between alemtuzumab and thymoglobulin ( 18 vs. $15 \%, p=0.63)$. Adverse event rates were similar among all four treatment groups. Kaplan-Meier actuarial estimated patient survival among the study patients was $96 \%$ with alemtuzumab and $96 \%$ with conventional therapy $(\mathrm{p}=0.38)$. Among the high-risk patients, graft survival was $91 \%$ with alemtuzumab and $84 \%$ with rATG $(p=0.32)$. After censoring of data on deaths, the estimated rates of graft survival among high-risk patients were $91 \%$ with alemtuzumab and $91 \%$ with rATG $(\mathrm{p}=0.88)$.

The above findings were confirmed by a recent systematic review and meta-analysis [83] from ten randomised clinical trials that showed alemtuzumab induction has a lower risk of positive BPAR compared with induction with basiliximab and daclizumab combined [relative risk 0.54 ; 95\% confidence interval (CI) 0.37 $0.79 ; \mathrm{p}<0.01]$. However, no significant difference was observed in the risk of BPAR when alemtuzumab induction was compared with thymoglobulin ATG-Fresenius S (Fresenius, Munich, Germany) (relative risk 0.79; 95\% CI $0.52-1.21 ; \mathrm{p}=0.28$ ). There was no difference in graft loss, DGF, patient death, and new-onset diabetes mellitus after transplantation when alemtuzumab was compared with IL-2 receptor antibodies or thymoglobulin induction.

Alemtuzumab induction thus reduces the risk of BPAR when compared with IL-2 receptor antibodies but not thymoglobulin, and the benefits of both have not yet been studied to address their role in donation after circulatory death (DCD) transplantation.

\section{Thymoglobulin versus Eculizumab (Inhibitor of Terminal Complement Activation) in Renal Transplantation}

The data of Goh et al. [89] from Mayo Clinic combined eculizumab and rATG for patients with a baseline T- and/ or B-cell FXM channel shift $>300$ who underwent pre- 
transplant plasma exchange (PE) treatments to achieve both T-and B-cell FXM channel shifts $>300$ on the day of transplant. They compared it with a group receiving antiIL-2 antibody having no pre-transplant donor-specific antibody and rATG alone for kidney transplant recipients who were high risk but had both negative $\mathrm{T}$ - and Bcell flow cytometric cross-matches (FXM). They reported that, compared to the anti-IL-2 receptor antibody induction group, both groups treated with rATG demonstrated significant depletion of all T-cell subsets (CD3-positive cells) ( $\mathrm{p}=0.0001$ for $\mathrm{rATG}$ vs. the anti-IL-2 receptor antibody induction group; $\mathrm{p}=0.001$ for $\mathrm{rATG}+$ eculizumab vs. the anti-IL-2 receptor antibody group). However, while T-cell counts were low in all rATG-treated patients, eculizumab treatment resulted in higher peripheral blood T-cell counts in rATG-treated patients $(\mathrm{p}=0.005)$. They concluded that eculizumab appears to have a mild inhibitory effect on peripheral blood T-cell depletion by rATG in kidney transplant recipients. The combination of rATG + eculizumab has added use in positive crossmatch kidney transplants without increasing the risk of ACR compared to the control group similar to other studies $(p=0.0031)$ [90]. These observations are consistent with the findings of previous in vitro studies that in vivo T-cell depletion by rATG in kidney transplant recipients might be partly but not entirely dependent on the complement.

\section{Does Thymoglobulin Increase Risk of Post-Transplant Lymphoproliferative Disorder?}

Post-transplant lymphoproliferative disorder (PTLD) is a relatively rare but well-known complication after organ transplantation. The recognised risk factors for PTLD are Epstein-Barr virus (EBV) serology and use of a potent immunosuppressive regimen [91-95]. Exposure to a newer and potent immunosuppression has led to a trend towards increasing the incidence of PTLD and earlier occurrence of PTLD [91, 92, 96]. Opelz et al. [97] showed that patients receiving thymoglobulin had a significant increased risk of lymphoma probably caused by inhibition of T-cell control which allows the uninhibited growth of B cells. Other studies however claim that thymoglobulin use in lower doses does not increase the risk of PTLD $[58,75,98]$.

Unfortunately, up-to-date literature only highlights a few studies to assess this problem. Dharnidharka and Stevens [99] analysed the UNOS (United Network for Organ Sharing) data of 87,407 patients and showed that male gender and Caucasian were associated with a significantly high relative risk for PTLD. In an adjusted analysis, the adjusted relative risk for PTLD development was significantly higher with the eATG or ALG but not with rATG. There was however no EBV serology data available from UNOS for further analysis.

Caillard et al. [91] who retrospectively analysed 25,127 patients reported that recipient age $<20$ years, pre-transplant malignancy, higher HLA match, and occurrence of rejection in the first year were associated with the development of PTLD. In addition, OKT3 usage was associated with a greater risk of PTLD, but not thymoglobulin. The authors do highlight a possible limitation in that the number of patients who received thymoglobulin was small $(\mathrm{n}=684)$. Further subanalysis showed a quadruple immunosuppressive regimen and patients who received tacrolimus versus cyclosporine are at increased risk of developing PTLD, suggesting that the culprit is probably a high immunosuppressive burden.

Another recent study in a cohort of 53,719 patients had shown that Caucasian, EBV-negative recipients, de novo sirolimus treatment, recipient with history of malignancy and rejection within the first year of transplantation were associated with a high risk of PTLD. The African-American kidney transplant recipients were at lower risk of developing PTLD irrespective of recipient EBV status [100]. Although the use of monoclonal and polyclonal agents per se did not increase the risk of PTLD, when used with calcineurin inhibitors the risk increased significantly.

A recent prospective, randomised, double-blinded study by Hardinger et al. [101] showed that there is no increase in the incidence of cancer and PTLD. Overall, there was a lower incidence of non-cutaneous malignancy in the thymoglobulin group compared to the Atgam group at 10 years of follow-up ( 6 vs. $17 \%, p=N S$ ). There were no cases of PTLD in the thymoglobulin group and 2 cases in the Atgam group. This is the only study with a 10 -year follow-up after thymoglobulin induction. Brennan et al. [45] observed similar findings, there being no significant difference in the incidence of cancer (including PTLD) when comparing with basiliximab. However, Kirk et al. [102] have shown that the overall incidence of PTLD was $0.42 \%$ and differed significantly by induction strategy ( $\mathrm{p}=0.01)$ (without induction $(0.43 \%)$, basiliximab $(0.38 \%)$, daclizumab $(0.33 \%)$, thymoglobulin $(0.67 \%)$, and alemtuzumab $(0.37 \%))$. Thymoglobulin was associated with a significantly increased PTLD risk ( $\mathrm{p}=$ $0.0025)$, but alemtuzumab $(\mathrm{p}=0.74)$ and basiliximab $(\mathrm{p}=0.33)$, which trended toward a protective effect $(\mathrm{p}=$ 0.06 ), were not. It has also been noted in these studies that 
PTLD is more clearly related with a maintenance immunosuppressive regimen rather than use of any particular drug. Reduction of this immunosuppression burden is thus associated with a decrease in the risk of PTLD [45, 102].

\section{Dosing of Thymoglobulin}

The initial trials establishing efficacy and safety of rATG were conducted using doses starting at $10.5 \mathrm{mg} / \mathrm{kg}$ $[1,103]$. Full-dose $\mathrm{rATG}$ induction therapy $(7-10 \mathrm{mg} / \mathrm{kg})$ has been associated with increased morbidity in the early post-transplant period $[42,104]$. An attempt at establishing a lower dosing regimen for $\mathrm{ATG}$ has been described in several studies [105-107].

Hardinger et al. [106] reported the results of induction with rATG $3 \mathrm{mg} / \mathrm{kg}$ intra-operatively followed by $1.5 \mathrm{mg} /$ $\mathrm{kg}$ on POD 1 and 2 in 40 renal transplant recipients as compared with a historical control group. Patients were generally low-risk and this study did show the efficacy of induction therapy (low dose) with a short course of rATG. In an attempt to establish an optimal dose, Wong et al. [108] evaluated the degree and durability of T-cell clearances with two different thymoglobulin regimens in adult kidney transplant recipients: group I had a 3-day thymoglobulin-based induction of $1.0 \mathrm{mg} / \mathrm{kg} / \mathrm{day}$, while group II received $1.5 \mathrm{mg} / \mathrm{kg} / \mathrm{day}$ in addition to maintenance immunosuppression. They concluded that thymoglobulin induction was efficacious in both groups, but with a significantly sustained T-cell clearance in the $1.5-\mathrm{mg} / \mathrm{kg} / \mathrm{day}$ regimen up to the first 6 months post-induction therapy. They suggested that this may translate into a decreased risk of immunological injury and possibly improve the long-term outcome after kidney transplantation.

Interestingly, Büchler et al. [109] in an attempt to optimise the dose and regimen of $\mathrm{rATG}$, administered rATG at a total dose of $6 \mathrm{mg} / \mathrm{kg}$, administered either as $1.5 \mathrm{mg} /$ $\mathrm{kg} /$ day on days $0-3$ (group 1 ) or $3 \mathrm{mg} / \mathrm{kg}$ on days 0 and 3 (group 2). They showed that $\mathrm{rATG}$ induced a significant decrease in the proportion of naive $\mathrm{CD} 4^{+} \mathrm{T}$ cells, which plateaued after month 1 in group 1 and after month 6 in group 2 and concluded that their results suggest that the dosing regimen for rATG induction influences pharmacokinetic parameters without affecting the quality of immune reconstitution.

\section{Low-Risk Recipients}

Laftavi et al. [110] explored the benefit and risks associated with low-dose rATG (rATG; 3-5 mg/kg total vs. basiliximab) induction in a low-risk population. They showed that in recipients of live donor kidneys, 8-year patient and graft survivals were not different; however, low-dose rATG was associated with a lower rate of AR ( 7.8 vs. $35 \%$ basiliximab, $\mathrm{p}<0.01$ ) and better mean serum creatinine at 3 and 5 years ( 1.2 vs. $1.5, \mathrm{p}=0.02$ and 1.18 vs. $1.54, \mathrm{p}=0.04$, respectively). For deceased donor recipients, low-dose rATG was associated with a better long-term graft survival ( 86 vs. $76 \%$ basiliximab, $p=$ 0.02). Djamali et al. [111] showed that two immunosuppressive regimens based on $\mathrm{rATG}$ given daily or intermittently following the $\mathrm{CD}^{+} \mathrm{T}$ lymphocytes (measured by flow cytometry) offered similar T-cell depletion and effective immunosuppression, thus supporting low-dose intermittent ATG induction as there was no significant difference in renal graft function, the number of acute graft rejections, or ATG-related side effects and complications and a net saving of USD 760 per patient.

\section{High-Risk Recipients}

Klem et al. [112] have used rATG at $1.5 \mathrm{mg} / \mathrm{kg} /$ day for 3 doses (group I) or 4 doses (group II) to determine the impact of reduced exposure rATG in the prevention of AR. They reported 1-year AR rates were 10 and $11 \%$ in the 3 - and 4-dose cohorts, respectively, with $100 \%$ patient and graft survival at 1 year in both groups. They concluded that excellent protection against $\mathrm{AR}$, even in patients at increased risk, can be achieved with the potential for cost savings from a reduction in hospital stay $(\mathrm{p}=0.004)$ and medication administration. Similarly, Gurk-Turner et al. [103] in their regimen assessed group 1 receiving $\leq 7.5 \mathrm{mg} / \mathrm{kg}$ rATG and group 2 receiving $>7.5 \mathrm{mg} / \mathrm{kg}$ rATG. They showed that the incidence of biopsy-proven AR during the first 12 months did not differ between the groups ( 9.5 vs. $8.8 \%$, respectively, $\mathrm{p}=0.9$ ). Serum creatinine at 12 months was $1.6 \pm 0.7$ in group 1 and $1.8 \pm 1.0$ in group $2(p=0.3)$. There was no independent association between rATG dose and graft survival (hazard ratio $0.85, \mathrm{p}=0.79,95 \%$ CI $0.26-2.7$ for group 2 vs. group 1 ) or 1-year SCr (regression coefficient 0.02 for $\ln (\mathrm{SCr}), \mathrm{p}=$ 0.3 ; $95 \% \mathrm{CI}-0.01$ to 0.6 ), thus concluding that in highrisk kidney transplant recipients, total $\mathrm{rATG}$ doses $\leq 7.5$ $\mathrm{mg} / \mathrm{kg}$ are safe and effective in achieving a low rate of AR and graft outcomes comparable to higher doses.

The review of Deeks and Keating [113] highlighted that rATG induction in combination with immunosuppressive therapy is more effective in preventing episodes of acute renal graft rejection in adult renal transplant recipients than immunosuppressive therapy without induction. The efficacy of rATG induction is generally bet- 
ter than that of eATG induction and generally no different from that of basiliximab or low-dose daclizumab induction in this patient population. However, in highrisk patients, rATG induction was more effective than daclizumab or basiliximab induction in preventing acute renal graft rejection. Induction with rATG has thus developed with time where initial dosing has been reduced to a low-dose regimen, followed by evidence to suggest a low-dose regimen in the high-risk strategy group.

\section{Other Benefits}

The use of thymoglobulin may help to support a calcineurin inhibitor-sparing regimen. Larson et al. [114] conducted a prospective, randomised trial which has shown significant chronic vascular changes on biopsies when a combination of thymoglobulin and calcineurin inhibitors are used. Similarly, thymoglobulin use can help in achieving a steroid-free immunosuppression regimen in renal transplantation without decreasing graft and patient survival [48].

\section{Conclusion}

DGF and BPAR at 1 year are independent risk factors for decreased graft survival. The role of thymoglobulin is justified when risk stratification is carried out as it may reduce DGF, AR, could prolong graft survival and patient survival. Studies to assess thymoglobulin induction in patients with a low risk are controversial but a long-term follow-up to assess the impact on BPAR, DGF, patient and graft survival, at risk of PTLD and risk of opportunistic infections justifies a randomised multicentre international long-term follow-up study.

\section{Disclosure Statement}

The authors have no conflicts of interest to disclose.

\section{References}

$>1$ Brennan DC, Flavin K, Lowell JA, Howard TK, Shenoy S, Burgess S, Dolan S, Kano JM, Mahon M, Schnitzler MA, Woodward R, Irish W, Singer GG: A randomized, double-blinded comparison of thymoglobulin versus Atgam for induction immunosuppressive therapy in adult renal transplant recipients. Transplantation 1999;67:1011-1018.

-2 Sollinger H, Kaplan B, Pescovitz MD, Philosophe B, Roza A, Brayman K, Somberg K: Basiliximab versus antithymocyte globulin for prevention of acute renal allograft rejection. Transplantation 2001;72:1915-1919.

3 Gaber AO, First MR, Tesi RJ, Gaston RS, Mendez R, Mulloy LL, Light JA, Gaber LW, Squiers E, Taylor RJ, Neylan JF, Steiner RW, Knechtle S, Norman DJ, Shihab F, Basadonna G, Brennan DC, Hodge EE, Kahan BD, Kahan L, Steinberg S, Woodle ES, Chan L, Ham JM, Schroeder TJ: Results of the double-blind, randomized, multicenter, phase III clinical trial of thymoglobulin versus Atgam in the treatment of acute graft rejection episodes after renal transplantation. Transplantation 1998;66:29-37.

$\checkmark 4$ Hardinger KL, Schnitzler MA, Miller B, Lowell JA, Shenoy S, Koch MJ, Enkvetchakul D, Ceriotti C, Brennan DC: Five-year follow-up of thymoglobulin versus Atgam induction in adult renal transplantation. Transplantation 2004;78:136-141.
5 Metchnikoff E: Etudes sur la résorption des $>12$ Halloran PF: Immunosuppressive drugs for cellules. Ann Inst Pasteur 1899;13:737-769.

$\checkmark 6$ Woodruff MFA AN: Effect of lymphocyte depletion by thoracic duct fistula and administration of antilymphocyte serum on the survival of skin homografts in rats. Nature 1963; 200:702.

$>7$ Iwasaki Y, Porter KA, Amend JR, Marchioro TL, Zühlke V, Starzl TE: The preparation and testing of horse anti-dog and anti-human antilymphoid plasma or serum and its protein fractions. Surg Gynecol Obstet 1967;124:124.

8 Taylor HE, Ackman CFD, Horowitz I: Canadian clinical trial of antilymphocyte globulin in human renal allografts. Can Med Assoc J 1976;115:1205-1208.

$\checkmark 9$ Halloran P, Ludwin D, Aprile and the Canadian Multicentre Transplant Study Group: Comparison of antilymphocyte globulinimuran, cyclosporine, and antilymphocyte globulin-cyclosporine therapy for cadaver renal transplantation. Transplant Proc 1985;17: 1201-1203.

10 Hardy MA, Nowngrod R, Elberg A, Apple G: Use of ATG in steroid-resistant rejection. Transplantation 1980;29:162-164.1

11 Revillard JP: Immunopharmacology of thymoglobulin. Graft 1999;2:S6-S9. kidney transplantation. N Engl J Med 2004; 351:2715-2729.

13 Préville X, Nicolas L, Flacher M, Revillard J: A quantitative flow cytometry assay for the preclinical testing and pharmacological monitoring of rabbit antilymphocyte globulins (rATG). J Immunol Methods 2000;245:45-54.

14 Kreis H, Mansouri R, Descamps JM, Dandavino R, N'Guyen AT, Bach JF, Crosnier J: Antithymocyte globulin in cadaver kidney transplantation: a randomized trial based on $\mathrm{T}$-cell monitoring. Kidney Int 1981;19:438-444.

15 Mueller TF: Mechanisms of action of thymoglobulin. Transplantation 2007;84:5-10.

16 Genestier L, Fournel S, Flacher M, Assossou O, Revillard JP, Bonnefoy-Berard N: Induction of Fas (Apo-1, CD95)-mediated apoptosis of activated lymphocytes by polyclonal antithymocyte globulins. Blood 1998;91:2360-2368.

17 Michallet MC, Preville X, Flacher M, Fournel S, Genestier L, Revillard JP: Functional antibodies to leukocyte adhesion molecules in antithymocyte globulins. Transplantation 2003; 75:657-662.

18 Préville X, Flacher M, LeMauff B, Beauchard S, Davelu P, Tiollier J, Revillard JP: Mechanisms involved in antithymocyte globulin immunosuppressive activity in a non-human primate model. Transplantation 2001;71: 460-468. 
$\checkmark 19$ Chappell D, Beiras-Fernandez A, Hammer C, Thein E: In vivo visualization of the effect of polyclonal antithymocyte globulins on the microcirculation after ischemia reperfusion in a primate model. Transplantation 2006;81: 552-558.

20 Clatworthy MR: Targeting B cells and antibody in transplantation. Am J Transplant 2011;11:1359-1367.

-21 Zand MS, Vo T, Huggins J, Felgar R, Liesveld J, Pellegrin T, Bozorgzadeh A, Sanz I, Briggs BJ: Polyclonal rabbit antithymocyte globulin triggers B-cell and plasma cell apoptosis by multiple pathways. Transplantation 2005;79: 1507-1515.

-22 Bächler K, Amico P, Hönger G, Bielmann D, Hopfer H, Mihatsch MJ, Steiger J, Schaub S: Efficacy of induction therapy with ATG and intravenous immunoglobulins in patients with low level donor-specific HLA antibodies. Am J Transplant 2010;10:1254-1262.

-23 Perry DK, Burns JM, Pollinger HS, Amiot BP, Gloor JM, Gores GJ, Stegall MD: Proteasome inhibition causes apoptosis of normal human plasma cells preventing alloantibody production. Am J Transplant 2009;9:201-209.

24 Mohty M: Mechanisms of action of antithymocyte globulin: T-cell depletion and beyond. Leukemia 2007;21:1387-1394.

-25 Gloor JM, Moore SB, Schneider BA, Degoey SR, Stegall MD: The effect of antithymocyte globulin on anti-human leukocyte antigen antibody detection assays. Transplantation 2007;84:258-264.

-26 Brayman K: New insights into the mechanisms of action of thymoglobulin. Transplantation 2007;84:S3-S4.

$\checkmark 27$ Hammer C Thein E: Visualization of the effect of polyclonal antithymocyte globulins on adhesion of leukocytes. Transplant Proc 2002; 34:2486-2487.

-28 Wood KJ Sakaguchi S: Regulatory T cells in transplantation tolerance. Nat Rev Immunol 2003;3:199-210.

29 Sakaguchi S, Sakaguchi N: Regulatory T cells in immunologic self-tolerance and autoimmune disease. Int Rev Immunol 2005;24:211226.

30 Salama AD, Najafian N, Clarkson MR, Harmon WE, Sayegh MH: Regulatory CD25 $5^{+} \mathrm{T}$ cells in human kidney transplant recipients. J Am Soc Nephrol 2003;14:1643-1651.

- 31 Feng X, Kajigaya S, Solomou EE, Keyvanfar K, Xu X, Raghavachari N, Munson PJ, Herndon TM, Chen J, Young NS: Rabbit ATG but not horse ATG promotes expansion of functional $\mathrm{CD} 4^{+} \mathrm{CD} 25^{\text {high }} \mathrm{Foxp}^{+}$regulatory $\mathrm{T}$ cells in vitro. Blood 2008;111:3675-3683.

- 32 Lopez M, Clarkson MR, Albin M, Sayegh MH, Najafian N: A novel mechanism of action for anti-thymocyte globulin: induction of $\mathrm{CD}^{+} \mathrm{CD} 25^{+} \mathrm{Foxp}^{+}$regulatory T cells. J Am Soc Nephrol 2006; 17:2844-2853.
33 LaCorcia G, Swistak M, Lawendowski C, Duan S, Weeden T, Nahill S, Williams JM, Dzuris JL: Polyclonal rabbit antithymocyte globulin exhibits consistent immunosuppressive capabilities beyond cell depletion. Transplantation 2009;87:966-974.

34 Beiras-Fernandez A, Walther S, Thein E, Muenzing S, Hammer C: Influence of polyclonal ATGs on expression of adhesion molecules: an experimental study. Transplant Proc 2005;37:1944-1946.

35 Zeevi A, Husain S, Spichty KJ, Raza K, Woodcock JB, Zaldonis D, Carruth LM, Kowalski RJ, Britz JA, McCurry KR: Recovery of functional memory $\mathrm{T}$ cells in lung transplant recipients following induction therapy with alemtuzumab. Am J Transplant 2007;7:471475.

36 Maki T, Gottschalk R, Wood ML, Monaco AP: Specific unresponsiveness to skin allografts in anti-lymphocyte serum-treated, marrow-injected mice: participation of donor marrow-derived suppressor T cells. J Immunol 1981;127:1433-1438.

37 Hale DA, Gottschalk R, Umemura A, Maki T, Monaco AP: Immunologic mechanisms in tolerance produced in mice with nonradiation-based lymphoablation and donor-specific bone marrow. Transplantation 2002;74: 477-484.

38 Hale DA, Gottschalk R, Umemura A, Maki T, Monaco AP: Establishment of stable multilineage hematopoietic chimerism and donorspecific tolerance without irradiation. Transplantation 2000;69:1242-1251.

39 Liu Z, Fang Y, Wang X, Wang P, Yun P, Xu $\mathrm{H}$ : Upregulation of molecules associated with T-regulatory function by thymoglobulin pretreatment of human $\mathrm{CD}^{+}$cells. Transplantation 2008;86:1419-1426.

40 Guttmann RD, Caudrelier P, Alberici G, Touraine JL: Pharmacokinetics, foreign protein immune response, cytokine release, and lymphocyte subsets in patients receiving thymoglobulin and immunosuppression. Transplant Proc 1997;29:24-26.

41 Beiras-Fernandez A, Thein E, Chappel D, Gallego R, Fernandez-Roel D, Kemming G, Hammer C: Polyclonal anti-thymocyte globulins influence apoptosis in reperfused tissues after ischaemia in anon-human primate model. Transpl Int 2004; 17:453-457.

-42 Clesca P, Dirlando M, Park SI, García R, Ferraz E, Pinheiro-Machado PG, Kushnaroff L, Tedesco-Silva H Jr, Medina-Pestana JO: Thymoglobulin and rate of infectious complications after transplantation. Transplant Proc 2007;39:463-464.

43 Lebranchu Y, Bridoux F, Büchler M, Le Meur Y, Etienne I, Toupance O, Hurault de Ligny B, Touchard G, Moulin B, Le Pogamp P, Reigneau O, Guignard M, Rifle G: Immunoprophylaxis with basiliximab compared with antithymocyte globulin in renal transplant patients receiving $\mathrm{MMF}$-containing triple therapy. Am J Transplant 2002;2:48-56.
44 Mourad G, Rostaing L, Legendre C, Garrigue V, Thervet E, Durand D: Sequential protocols using basiliximab versus antithymocyte globulins in renal-transplant patients receiving mycophenolate mofetil and steroids. Transplantation 2004;78:584-590.

45 Brennan DC, Daller JA, Lake KD, Cibrik D, Del Castillo D: Rabbit antithymocyte globulin versus basiliximab in renal transplantation. N Engl J Med 2006;355:1967-1977.

46 Mullen JC, Oreopoulos A, Lien DC, Bentley MJ, Modry DL, Stewart K, Winton TL, Jackson K, Doucette K, Preiksaitis J, Halloran PF: A randomized, controlled trial of daclizumab vs. anti-thymocyte globulin induction for lung transplantation. J Heart Lung Transplant 2007;26:504-510.

-47 Abou-Ayache R, Büchler M, Lepogamp P, Westeel PF, Le Meur Y, Etienne I, Lobbedez T, Toupance O, Caillard S, Goujon JM, Bergougnoux L, Touchard G: CMV infections after two doses of daclizumab versus thymoglobulin in renal transplant patients receiving mycophenolate mofetil, steroids and delayed cyclosporine A. Nephrol Dial Transplant 2008;23:2024-2032.

-48 Woodle ES, Peddi VR, Tomlanovich S, Mulgaonkar S, Kuo PC: A prospective, randomized, multicenter study evaluating early corticosteroid withdrawal with thymoglobulin in living-donor kidney transplantation. Clin Transpl 2010;24:73-83.

49 Massberg S, Messmer K: The nature of ischemia/reperfusion injury. Transplant Proc 1998;30:4217-23.

50 Rabb H, Daniels F, O’Donnell M, Haq M, Saba SR, Keane W, Tang WW: Pathophysiological role of $\mathrm{T}$ lymphocytes in renal ischemia-reperfusion injury in mice. Am J Physiol Renal Physiol 2000;279:F525-F531.

51 Yokota N, Daniels F, Crosson J, Rabb H: Protective effect of T-cell depletion in murine renal ischemia-reperfusion injury. Transplantation 2002;74:759-763.

52 De Greef KE, Ysebaert DK, Dauwe S, Persy V, Vercauteren SR, Mey D, De Broe ME: AntiB7-1 blocks mononuclear cell adherence in vasa recta after ischemia. Kidney Int 2001;60: 1415-1427.

53 Wang S, Diao H, Guan Q, Cruikshank WW, Delovitch TL, Jevnikar AM, Du C: Decreased renal ischemia-reperfusion injury by IL-16 inactivation. Kidney Int 2008;73:318-323.

54 Inman SR, Davis NA, Mazzone ME, Olson KM, Lukaszek VA, Yoder KN: Simvastatin and $\mathrm{L}$-arginine preserve renal function after ischemia/reperfusion injury. Am J Med Sci 2005;329:13-17.

55 Bogetti D, Sankary HN, Jarzembowski TM, Manzelli A, Knight PS, Thielke J, Chejfec G, Cotler S, Oberholzer J, Testa G, Benedetti E: Thymoglobulin induction protects liver allografts from ischemia/reperfusion injury. Clin Transpl 2005;19:507-511. 
-56 Beiras-Fernandez A, Chappell D, Hammer C, Beiras A, Reichart B, Thein E: Impact of polyclonal anti-thymocyte globulins on the expression of adhesion and inflammation molecules after ischemia-reperfusion injury. Transpl Immunol 2009;20:224-228.

- 57 Jang HR, Gandolfo MT, Ko GJ, Racusen L, Rabb H: The effect of murine anti-thymocyte globulin on experimental kidney warm ischemia-reperfusion injury in mice. Transpl Immunol 2009;22:44-54.

58 Goggins WC, Pascual MA, Powelson JA, Magee C, Tolkoff-Rubin N, Farrell ML, Ko DS, Williams WW, Chandraker A, Delmonico FL, Auchincloss H, Cosimi AB: A prospective, randomized, clinical trial of intraoperative versus postoperative thymoglobulin in adult cadaveric renal transplant recipients. Transplantation 2003;76:798-802.

-59 Patel SJ, Duhart BT Jr, Krauss AG, Moore LW, Egidi MF, Amiri HS, Gaber LW, Gaber AO: Risk factors and consequences of delayed graft function in deceased donor renal transplant patients receiving antithymocyte globulin induction. Transplantation 2008;86:313-320.

60 Noël C, Abramowicz D, Durand D, Mourad G, Lang P, Kessler M, Charpentier B, Touchard G, Berthoux F, Merville P, Ouali N, Squifflet JP, Bayle F, Wissing KM, Hazzan M: Daclizumab versus antithymocyte globulin in high-immunological-risk renal transplant recipients. J Am Soc Nephrol 2009;20: 1365-1392.

-61 Gjertson DW: Determinants of long-term survival of adult kidney transplants: a 1999 UNOS update. Clin Transpl 1999:341-352.

62 Hariharan S: Long-term kidney transplant survival. Am J Kidney Dis 2001;38:44-50.

- 63 Hariharan S, Johnson CP, Bresnahan BA, Taranto SE, McIntosh MJ, Stablein D: Improved graft survival after renal transplantation in the United States, 1988 to 1996. N Engl J Med 2000;342:605-612.

64 Lindholm A, Ohlman S, Albrechtsen D, Tufveson G, Persson H, Persson NH: The impact of acute rejection episodes on long-term graft function and outcome in 1,347 primary renal transplants treated by three cyclosporine regimens. Transplantation 1993;56:307-315.

-65 Martin ST, Roberts KL, Malek SK, Tullius SG, Vadivel N, De Serres S, Grafals M, Elsanjak A, Filkins BA, Chandraker A, Gabardi S: Induction treatment with rabbit antithymocyte globulin versus basiliximab in renal transplant recipients with planned early steroid withdrawal. Pharmacotherapy 2011;31:566573.

-66 Kamel MH, Mohan P, Little DM, Awan A, Hickey DP: Rabbit antithymocyte globulin as induction immunotherapy for pediatric deceased donor kidney transplantation. J Urol 2005;174:703-707.

-67 Shenoy M, Roberts D, Plant ND, Lewis MA, Webb NJ: Antithymocyte treatment of steroid-resistant acute rejection in renal transplantation. Pediatr Nephrol 2011;26:815818.
68 Tian JH, Wang X, Yang KH, Liu AP, Luo XF, Zhang J: Induction with and without antithymocyte globulin combined with cyclosporine/tacrolimus-based immunosuppression in renal transplantation: a meta-analysis of randomized controlled trials. Transplant Proc 2009;41:3671-3676.

69 Emami S, Huang E, Kuo HT, Kamgar M, Bunnapradist S: Multivariate analysis of antibody induction therapy and their associated outcomes in live donor kidney transplantation in the recent era. Clin Transpl 2012;26:315-318.

70 Knight RJ, Kerman RH, Schoenberg L, Podder H, Van Buren CT, Katz S, Kahan BD: The selective use of basiliximab versus thymoglobulin in combination with sirolimus for cadaveric renal transplant recipients at low risk versus high risk for delayed graft function. Transplantation 2004;78:904-910.

71 Libório AB, Mendoza TR, Esmeraldo RM, Oliveira ML, Paes FJ, Silva Junior GB, Daher EF: Induction antibody therapy in renal transplantation using early steroid withdrawal: long-term results comparing anti-IL-2 receptor and anti-thymocyte globulin. Int Immunopharmacol 2011;11:1832-1836.

72 Ciancio G, Burke GW, Gaynor JJ, Carreno MR, Cirocco RE, Mathew JM, Mattiazzi A, Cordovilla T, Roth D, Kupin W, Rosen A, Esquenazi V, Tzakis AG, Miller J: A randomized trial of three renal transplant induction antibodies: early comparison of tacrolimus, mycophenolate mofetil, and steroid dosing, and newer immune-monitoring. Transplantation 2005;80:457-465.

73 Campbell SB, Hothersall E, Preston J, Brown AM, Hawley CM, Wall D, Griffin AD, Isbel NM, Nicol DL, Johnson DW: Frequency and severity of acute rejection in live- versus cadaveric-donor renal transplants. Transplantation 2003;76:1452-1457.

74 Wiland AM, Fink JC, Weir MR, Philosophe B, Blahut S, Weir MR Jr, Copenhaver B, Bartlett ST: Should living-unrelated renal transplant recipients receive antibody induction? Results of a clinical experience trial. Transplantation 2004;77:422-425.

75 Hardinger KL, Schnitzler MA, Koch MJ, Labile E, Stirnemann PM, Miller B, Enkvetchakul D, Brennan DC: Thymoglobulin induction is safe and effective in live donor renal transplantation: a single-center experience. Transplantation 2006;81:1285-1289.

76 Gaber AO, Matas AJ, Henry ML, Brennan DC, Stevens RB, Kapur S, Ilsley JN, Kistler KD, Cosimi AB: Thymoglobulin antibody immunosuppression in living donor recipients investigators. antithymocyte globulin induction in living donor renal transplant recipients: final report of the Tailor Registry. Transplantation 2012;94:331-337.

-77 Schenker P, Ozturk A, Vonend O, Krüger B, Jazra M, Wunsch A, Krämer B, Viebahn R: Single-dose thymoglobulin induction in living-donor renal transplantation. Ann Transplant 2011;16:50-58
8 Ciancio G, Gaynor JJ, Roth D, Kupin W, Hanson L, Tueros L, Zarak A, Ruiz P, Burke GW 3rd: Randomized trial of thymoglobulin versus alemtuzumab (with lower dose maintenance immunosuppression) versus daclizumab in living donor renal transplantation. Transplant Proc 2010;42:3503-3506.

79 Martins L, Fonseca I, Almeida M, Henriques AC, Dias L, Sarmento AM, Cabrita A: Immunosuppression with antithymocyte globulin in renal transplantation: better long-term graft survival. Transplant Proc 2005;37:2755-2758.

80 Abouna GM, Kumar MS, Stephan R, Prior JE, Lyons P, Bulova SI, al-Abdullah IH: Induction therapy with ATG reduces the incidence of allograft rejection and improves graft survival in cadaver renal transplantation. Transplant Proc 1993;25:2241-2242.

81 Willoughby LM, Schnitzler MA, Brennan DC, Pinsky BW, Dzebisashvili N, Buchanan PM, Neri L, Rocca-Rey LA, Abbott KC, Lentine KL: Early outcomes of thymoglobulin and basiliximab induction in kidney transplantation: application of statistical approaches to reduce bias in observational comparisons. Transplantation 2009;87:15201529.

82 Noël C, Abramowicz D, Durand D, Mourad G, Lang P, Kessler M, Charpentier B, Touchard G, Berthoux F, Merville P, Ouali N, Squifflet JP, Bayle F, Wissing KM, Hazzan M: Daclizumab versus antithymocyte globulin in high-immunological-risk renal transplant recipients. J Am Soc Nephrol 2009;20:13851392.

83 Morgan RD, O'Callaghan JM, Knight SR, Morris PJ: Alemtuzumab induction therapy in kidney transplantation: a systematic review and meta-analysis. Transplantation 2012;93: 1179-1188.

84 Hale G, Xia MQ, Tighe HP, Dyer MJ, Waldmann H: The Campath-1 antigen (CDw52). Tissue Antigens 1990;35:118-127.

85 Fox EJ: Alemtuzumab in the treatment of relapsing-remitting multiple sclerosis. Expert Rev Neurother 2010;10:1789-1797.

86 Kanda J, Lopez RD, Rizzieri DA: Alemtuzumab for the prevention and treatment of graft-versus-host disease. Int J Hematol 2011; 93:586-593.

-87 Thomas PG, Woodside KJ, Lappin JA, Vaidya S, Rajaraman S, Gugliuzza KK: Alemtuzumab (Campath-1H) induction with tacrolimus monotherapy is safe for high immunological risk renal transplantation. Transplantation 2007;83:1509-1512.

88 Hanaway MJ, Woodle ES, Mulgaonkar S, Peddi VR, Kaufman DB, First MR, Croy R, Holman J, INTAC Study Group: Alemtuzumab induction in renal transplantation. $\mathrm{N}$ Engl J Med 2011;364:1909-1919.

89 Goh BK, Chedid MF, Gloor JM, Raghavaiah S, Stegall MD: The impact of terminal complement blockade on the efficacy of induction with polyclonal rabbit antithymocyte globulin in living donor renal allografts. Transpl Immunol 2012;27:95-100. 
-90 Stegall MD, Diwan T, Raghavaiah S, Cornell LD, Burns J, Dean PG, Cosio FG, Gandhi MJ, Kremers W, Gloor JM: Terminal complement inhibition decreases antibody-mediated rejection in sensitized renal transplant recipients. Am J Transplant 2011;11:2405-2413.

-91 Caillard S, Dharnidharka V, Agodoa L, Bohen E, Abbott K: Posttransplant lymphoproliferative disorders after renal transplantation in the United States in era of modern immunosuppression. Transplantation 2005;80:12331243.

92 Cherikh WS, Kauffman HM, McBride MA, Maghirang J, Swinnen LJ, Hanto DW: Association of the type of induction immunosuppression with posttransplant lymphoproliferative disorder, graft survival, and patient survival after primary kidney transplantation. Transplantation 2003;76:1289-1293.

93 Opelz G, Daniel V, Naujokat C, Döhler B: Epidemiology of pretransplant EBV and CMV serostatus in relation to posttransplant nonHodgkin lymphoma. Transplantation 2009; 88:962-967.

94 Shahinian VB, Muirhead N, Jevnikar AM, Leckie SH, Khakhar AK, Luke PP, Rizkalla KS, Hollomby DJ, House AA: Epstein-Barr virus seronegativity is a risk factor for lateonset posttransplant lymphoproliferative disorder in adult renal allograft recipients. Transplantation 2003;75:851-856.

-95 Opelz G DB: Lymphomas after solid organ transplantation: a collaborative transplant study report. Am J Transplant 2004;4:222230.

96 Shroff R Rees L: The post-transplant lymphoproliferative disorder - a literature review. Pediatr Nephrol 2004;19:369-377.

\$97 Opelz G, Naujokat C, Daniel V, Terness P, Döhler B: Disassociation between risk of graft loss and risk of non-Hodgkin lymphoma with induction agents in renal transplant recipients. Transplantation 2006;81:1227-1233.

98 Kremers WK, Devarbhavi HC, Wiesner RH, Krom RA, Macon WR, Habermann TM: Post-transplant lymphoproliferative disorders following liver transplantation: incidence, risk factors and survival. Am J Transplant 2006;6:1017-1024.

-99 Dharnidharka VR, Stevens G: Risk for posttransplant lymphoproliferative disorder after polyclonal antibody induction in kidney transplantation. Pediatr Transplant 2005;9: 622-626.
100 Nee R, Hurst FP, Dharnidharka VR, Jindal RM, Agodoa LY, Abbott KC: Racial variation in the development of posttransplant lymphoproliferative disorders after renal transplantation. Transplantation 2011;92: 190-195.

101 Hardinger KL, Rhee S, Buchanan P, Koch M, Miller B, Enkvetchakul D, Schuessler R, Schnitzler MA, Brennan DC: A prospective, randomized, double-blinded comparison of thymoglobulin versus Atgam for induction Immunosuppressive therapy: 10 year results. Transplantation 2008;86:947-952.

102 Kirk A, Cherikh W, Ring M, Burke G, Kaufman D, Knechtle S, Potdar S, Shapiro R, Dharnidharka V, Kauffman H: Dissociation of T-cell depletion and post-transplant lymphoproliferative disease in kidney recipients treated with alemetuzumab. Am J Transplant 2007;7:2619-2625.

103 Gurk-Turner C, Airee R, Philosophe B, Kukuruga D, Drachenberg C, Haririan A: Thymoglobulin dose optimization for induction therapy in high-risk kidney transplant recipients. Transplantation 2008;85:1425-1430.

104 Laftavi MR, Patel S, Soliman MR, Alnimri M, Kohli R, Said M, Pankewycz O: Low-dose thymoglobulin use in elderly renal transplant recipients is safe and effective induction therapy. Transplant Proc 2011;43:466468.

105 Agha IA, Rueda J, Alvarez A, Singer GG, Miller BW, Flavin K, Lowell JA, Shenoy S, Howard TK, Ramachandran V, Irish W, Schnitzle MA, Brennan DC: Short course induction immunosuppression with thymoglobulin for renal transplant recipients. Transplantation 2002;73:473-475.

106 Hardinger KL, Bohl DL, Schnitzler MA, Lockwood M, Storch GA, Brennan DC: A randomized, prospective, pharmacoeconomic trial of tacrolimus versus cyclosporine in combination with thymoglobulin in renal transplant recipients. Transplantation 2005;80:41-46.
107 Peddi VR, Bryant M, Roy-Chaudhury P, Woodle ES, First MR: Safety, efficacy, and cost analysis of thymoglobulin induction therapy with intermittent dosing based on CD3 lymphocyte counts in kidney and kidney-pancreas transplant recipients. Transplantation 2002;73:1514-1518.

108 Wong W, Agrawal N, Pascual M, Anderson DC, Hirsch HH, Fujimoto K, Cardarelli F, Winkelmayer WC, Cosimi AB, Tolkoff-Rubin N: Comparison of two dosages of thymoglobulin used as a short-course for induction in kidney transplantation. Transpl Int 2006;19:629-635.

109 Büchler M, Longuet $\mathrm{H}$, Lemoine R, Herr F, Gatault P, Thibault G, Ternant D, Foulon C, Pilorge B, Lemay D, Sung C, Halimi JM, Baron $\mathrm{C}$, Lebranchu Y: Pharmacokinetic and pharmacodynamic studies of two different rabbit antithymocyte antiglobulin dosing regimens: results of a randomized trial. Transpl Immunol 2013;28:120-126.

110 Laftavi MR, Alnimri M, Weber-Shrikant E, Kohli R, Said M, Patel S, Pankewycz O: Lowdose rabbit antithymocyte globulin versus basiliximab induction therapy in low-risk renal transplant recipients: 8-year followup. Transplant Proc 2011;43:458-461.

111 Djamali A, Turc-Baron C, Portales P, Leverson G, Chong G, Clot J, Mourad G: Lowdose antithymocyte globulins in renal transplantation: daily versus intermittent administration based on T-cell monitoring. Transplantation 2000;69:799-805.

112 Klem P, Cooper JE, Weiss AS, Gralla J, Owen P, Chan L, Wiseman AC: Reduced dose rabbit anti-thymocyte globulin induction for prevention of acute rejection in high-risk kidney transplant recipients. Transplantation 2009;88:891-896.

113 Deeks ED, Keating G: Rabbit antithymocyte globulin (thymoglobulin): a review of its use in the prevention and treatment of acute renal allograft rejection. Drugs 2009;69:14831512.

114 Larson TS, Dean PG, Stegall MD, Griffin MD, Textor SC, Schwab TR, Gloor JM, Cosio FG, Lund WJ, Kremers WK, Nyberg SL, Ishitani MB, Prieto M, Velosa JA: Complete avoidance of calcineurin inhibitors in renal transplantation: a randomized trial comparing sirolimus and tacrolimus. Am J Transplant 2006;6:514-522. 